\title{
Country cousins: Europeanness, sexuality and locality in contemporary Italian television
}

\author{
Martin Dines $^{\mathrm{a} *}$ and Sergio Rigoletto ${ }^{\mathrm{b \dagger}}$ \\ a Department of Humanities, Kingston University, London, UK; ${ }^{b}$ Department of Modern \\ Languages and European Studies, University of Reading, Reading, UK
}

(Received 21 October 2011; final version accepted 26 April 2012)

\begin{abstract}
This article examines the consequences of the concurrence of a recent surge of interest in LGBT lives in the Italian media with the perceived transformation of Spain. Long considered Italy's close - though inferior - cultural cousin, Spain has been seen to be forging its own path with the reforms of the Zapatero administration, gay marriage especially. The article focuses on Il padre delle spose (RAIl, 2006), which generated intense discussion across the political spectrum precisely during the period in which the issue of recognising domestic partnerships between same-sex couples was being contested in Italy. The drama and surrounding media debates are analysed in order to articulate both the anxieties and the sense of opportunity brought about by Spain's 'sorpasso' of Italy. The drama is also informative for the way it reverses the standard 'metropolitan' trajectory of LGBT narrative. By relocating its lesbian protagonists to rural Puglia, the drama indicates how local traditions might be better able to respond to hetero-patriarchal oppression than imported ideals of 'coming out'. Further, the drama's emphasis on local forms of solidarity suggests an alternative vision of LGBT existence to the one increasingly dominant across Europe and the West which privileges economically productive subjects.
\end{abstract}

Keywords: same-sex marriage; television; Europeanness; Zapatero; Puglia; coming out

First broadcast on the main Italian state channel RAI1 on 21 November 2006, the singleepisode television drama Il padre delle spose focuses on two lesbian women, Aurora, an Italian photographer, and Rosario, a Spanish flamenco teacher. They are happily married to each other and have forged successful careers in Barcelona where they live, but are obliged to relocate suddenly to Aurora's hometown in rural Puglia where their relationship receives neither legal recognition nor social approbation. The drama attracted over seven million viewers and generated heated discussion across the political spectrum both before and after its scheduled broadcasting. Much of the controversy surrounding $\mathrm{Il}$ padre delle spose was caused by its engagement with the issue of same-sex marriage. MP Carlo Giovanardi, for example, attacked RAI for its decision to broadcast the drama and declared that by showing gay marriage as a viable choice, the TV drama sent a dangerous message that threatened the future of Italian society (Franco 2006, 52). ${ }^{1}$ Il padre delle spose

\footnotetext{
*Corresponding author. Email: m.dines@kingston.ac.uk

${ }^{\dagger}$ Current address: Romance Languages/Cinema Studies, University of Oregon, Eugene, USA.
} 
attracted such outraged responses in part because it appeared in a period in which a vigorous public debate over the legalisation of civil partnerships and the recognition of particular rights for gay couples was taking place in Italy. This debate intensified in the months immediately before the general elections that led to the second Prodi government (May 2006-May 2008), a period during which the parties of the centre-left coalition appeared open to the possibility of passing a law recognising civil partnerships for both heterosexual and same-sex couples. ${ }^{2}$

Il padre delle spose is by no means the first drama on Italian television to be centrally about homosexuality; indeed, it was produced during a period of increased interest in LGBT life and politics in Italian mainstream culture in the wake of the enormously controversial World Gay Pride held in Rome in $2000 .^{3}$ This particular drama, however, is not only interesting for its presentation of the emerging possibilities and enduring difficulties of being LGBT in Italy. Our reason for focusing on Il padre delle spose here has to do with the way it invites a closer examination of the relationship between sexuality and locality. This matter has received some attention in relation to Italy, though often the interest is only passing. A number of scholars have begun to query ideas about the specificity and uniformity of marginal sexual and gender formations within Italy by considering how, for instance, the perspectives of immigrants might disrupt dominant narratives, both foreign and domestic, regarding the Italian sexual character (Duncan 2006, 3-4), and modes of sexual citizenship in Italy (Malagreca 2007, 25-39). Others have interrogated the influence and relevance of the Anglophone term 'queer' amongst activists and academics in Italy (Pustianaz 2010), a project which is also being pursued with some urgency elsewhere in Europe (see for example Mizielinska 2006; Downing and Gillett 2011). The significance of Il padre delle spose has to do with the way it contributes to such a discussion about the specificity of LGBT experience in Italy, whilst simultaneously directing attention towards local particularities within Italy.

On the one hand, we understand the drama to be questioning the straightforward importation and imposition of a 'metropolitan model' of sexual identity onto nonmetropolitan situations. This model, predominant in the Anglophone West, presumes that LGBT subjects assemble in urban-located subcultures, and is reinforced by prevailing forms of sexual identity narrative, in particular the coming-out story. Such narratives have, though, come under criticism for presuming a shared 'story' and identity that transcend local specificities: they tend to speak to individuals privileged by economic and social mobility whilst excluding an array of more economically disadvantaged non-urban, not to mention non-Western, subjectivities (Sinfield 2000; Spurlin 2000).

On the other hand, Il padre delle spose is interesting for its recognition of the ways regional, national and even supra-national institutions and identities interact to produce a complex politics of sexuality. The drama conveys a number of anxieties about Italy's current position amongst European nations following the reforms of the Zapatero government, which have appeared to propel Spain - once perceived to be Italy's inferior relative - to the progressive vanguard of Europe. We argue that in the drama and in broader discourse, Spain acts like an ambivalent double to Italy, standing for loss but also opportunity for social change. Equally, Il padre delle spose focuses on transformations that have been taking place within Italy. Rural Puglia, which provides the drama's setting, ultimately seems a hospitable environment for LGBT people - a turnaround which reflects the region's new path under the leadership of Nichi Vendola. 
Our analysis of the drama, however, suggests reasons to be cautious about claims relating to the supposed benefits that LGBT people bring to these provincial locales. These assertions, derived from the work of Richard Florida, ultimately conflate diversity, tolerance and creativity with economic productivity. Some commentators have interpreted Il padre delle spose as extending Florida's arguments about American cities to Italian rural contexts, yet the drama refuses to conceive of its lesbian protagonists purely as economic agents. We argue, moreover, that such neoliberal discourse leads to LGBT subjectivities being conceived too narrowly and reduces sensitivity towards the exigencies of provincial LGBT life. Necessarily our examination of the above issues ranges beyond their representation in Il padre delle spose: the drama stands as a faultline text which was hotly contested in the Italian media, and these debates also provide fruitful material with which to consider tensions relating to national identity, regionality and sexuality.

\section{Country cousins: Italy and Spain}

Il padre delle spose opens with some back-story located in rural Puglia. The young Aurora escapes to Spain to fulfil her ambition of becoming a photographer, much against her father Riccardo's wishes, who considers it an occupation quite unsuitable for a woman. The present-day story begins with Riccardo's accidental discovery, whilst on a business trip to Barcelona, that Aurora is married to another woman. Subsequently the drama is concerned with the consequences that their marriage has for Riccardo and, after they decide to follow him back to Puglia, for his small rural community. In Puglia, Rosario and Aurora become involved with the local townspeople's efforts to fend off the encroachments of a devious businessman who is attempting to buy up their olive groves so that he can produce inferior-quality oil at great profit. The businessman also finds out about Aurora and Rosario's relationship and blackmails Riccardo, threatening to out them and bring upon Riccardo utter shame unless he is allowed to pursue his plans unhindered. Ultimately the women's cover is blown by a different agent: Rosario's violent ex-husband, who is the reason why they have fled Spain, eventually finds them and attacks and seriously injures Aurora. The incident, and the women's relationship, is subsequently all over the local press, and the town's community comes to understand that they are not merely 'friends' after all. But so successful have the couple been in forging solidarity amongst the locality's women through their revival of dormant local forms of female association that they are welcomed back into the family and the wider community.

The drama's sequence of moves between Italy and Spain parallels the assumption, repeatedly made throughout $I l$ padre delle spose, that close ties connect the two countries. Often these affinities are couched in comforting domestic or familial terms. For instance, whilst in Barcelona, Riccardo jokes about his surname, Catalano, to imply his closeness to the region that has welcomed his daughter. When Rosario first sees the trulli, the traditional Apulian houses, she excitedly points out to Aurora how much they remind her of Andalucía. Yet, the fact that the drama oscillates between the urbanity of Barcelona and an Apulian backwater indicates that the relationship between the two countries is understood to be imbalanced.

Il padre delle spose is one of several Italian TV dramas, films and documentaries including Viva Zapatero (dir. Guzzanti 2005), Italo-spagnolo (MTV Italy 2006), Caterina e le sue figlie 2 \& 3 (Canale 5 2007; 2010), Ma la Spagna non era cattolica? (dir. Marcias 
2007) and Manuale d'amore 2 (dir. Veronesi 2007) - which explore national anxieties about the shifting relationship between Spain and Italy. These productions reflect on what has been described as the sorpasso of Italy by Spain after the widespread social and civil rights reforms enacted since 2004 by Jose Luis Rodriguez Zapatero's socialist government, foremost the legal recognition of gay marriage and of the right for gay couples to adopt children. ${ }^{4}$ As its title suggests, Peter Marcias's documentary Ma la Spagna non era cattolica? spells out from an Italian perspective the collective shock of a national culture that realises how its relationship with its close, yet culturally and economically inferior, double has suddenly become inverted. In Il padre delle spose, the asymmetry between the two countries in terms of their legal recognition of same-sex relations has direct personal consequences during Aurora's hospitalisation in Puglia after Rosario's ex-husband stabs her. Under Italian law, her marriage to Rosario is not recognised and Riccardo is legitimately able to prevent Rosario from seeing her wife in hospital. Similarly, in Manuale d'amore 2, Franco and Manuela, a straight couple travelling to Barcelona to undergo artificial insemination, turn to the camera and ask the audience what kind of country Italy is if it forces a couple like them, so desperate to have a baby, to go to Spain. In the same film a gay couple from Puglia played by Sergio Rubini and Antonio Albanese follow a similar trajectory and travel to Barcelona to fulfil their desire to get married. The journey from Italy to Spain is once again a journey of final fulfilment and emancipation away from the disappointments of provincial, backward Italy.

Throughout much of the second half of the twentieth century, the similarities between Italy and Spain have appeared obvious: both are southern, predominantly Catholic, romance language-speaking countries with similar economic and social profiles, featuring north-south divides as well as the presence of strong regional identities (Hooper 2008). As has been noted by some commentators, for Italians this relationship with their cugini has traditionally been comforting. According to Aldo Cazzullo (2008), 'l'Italia... ha guardato alla Spagna con un sorriso benevolente, finendo quasi per pensare gli spagnoli come un popolo fraternamente innocuo'. 5 This is a view, Hooper explains, based on the perception of Spain as a country still labouring to emerge culturally and economically from the shadow of General Francisco Franco's long dictatorship. It is a view that was particularly resonant in the 1980s when Spain was seen as a second-world country with an economy heavily reliant on rustbelt industries and possessing fewer library books per 100 inhabitants than Morocco. By contrast, in the same period, rich, fashionable Italy could claim to have become the fifth largest economy in the world (Hooper 2008).

Rather unsettlingly this relationship has recently been overturned. In 2006, for instance, Spain's GDP surpassed that of Italy. Following Spain's recent financial downturn precipitated by the collapse of its property market, the 'sorpasso' is less frequently articulated in economic terms. More likely the term's deployment relates to social and cultural change; certainly, this is the kind of change most resonant in the abovementioned films and documentaries. Il padre delle spose, for example, points to the matter of gender equality as a key faultline between the two nations by showing Spain as a place where young talented women such as Aurora have been able to fulfil their professional aspirations. By contrast, the section of the drama set in Puglia is striking for its portrayal of housewives frustrated by limited opportunities. Such stark asymmetry between the two locales is resonant of recent realignments in Southern Europe. In 2004, Spain's newly elected president Zapatero appointed an equal number of men and women as ministers, and on his re-election in 2008 appointed a predominantly female cabinet. These turning 
points in Spanish politics have resounded in Italy, with Italian Prime Minister Silvio Berlusconi declaring that Zapatero's new cabinet was 'troppo rosa e percio difficile da gestire' (Il Corriere della sera 2008). In the light of the recent prostitution and under-age sex scandals involving Berlusconi, this comment readily points to Italy's increasing distance from Spain in matters concerning social attitudes to women and other forms of cultural progress. Far from being a mere political gesture, the Zapatero government's commitment to gender equality reflects a wider change in Spanish attitudes towards women and gender roles, as exemplified by the recent extraordinary rise in female employment in Spain. ${ }^{6}$

Since the victory of the Socialist party in the 2004 general elections, Zapatero's Spain has become a constant reference point for many Italian cultural commentators and politicians. ${ }^{7}$ Neologisms such as 'zapaterista' and 'zapaterismo' have rapidly entered the Italian language. ${ }^{8}$ One of the most frequent related expressions to appear in Italian newspapers and magazines between 2004 and 2008 is 'deriva zapaterista', i.e. Zapaterist drift. Just a few days before the 2005 referendum on artificial insemination, the national newspaper La Repubblica reported that "Giovanardi parla di "una deriva alla Zapatero"" (Casadio 2005). In the wake of Equal Opportunities Minister Barbara Pollastrini's proposal in 2006 to pass a law that would have given legal status to civil partnerships also for same-sex couples, another article reported that 'Luca Volontè, capogruppo dell'Udc alla Camera, bacchetta quella che definisce una deriva zapaterista del governo' (La Repubblica 2006).

In these commentaries, the expression 'deriva zapaterista' synonymises a fear of secular radicalism infiltrating and taking control of Italian politics. In light of the perceived cultural proximity between the two countries and by means of the obsessive invocation of 'la deriva zapaterista', Spain appears repeatedly constructed as Italy's double, as an uncanny projection of a national collective 'noi' losing its stability and recognisable contours. Under these terms, Spain emerges as a reflection of what Italy could become, should the country lose sight of its perceived Catholic roots and its family-based moral and legal traditions.

The spectre of Zapatero's Spain was invoked in similar fashion in the media debates surrounding $I l$ padre delle spose. In response to the controversy surrounding the broadcasting of the drama, Mario Landolfi (president of the state television watchdog, Commissione vigilanza) asserted that RAI certainly needed to deal with controversial subjects such as homosexuality and the question of gay marriage. Landolfi noted that 'nessuno obbliga però la Rai a sposare acriticamente la tesi zapaterista, cioè a presentare il matrimonio tra persone dello stesso sesso e la loro possibilità di adottare bambini come un ampliamento naturale della sfera dei diritti individuali' (gaynews.it 2006b). References to the recent changes in Zapatero's Spain and the implications they have for Italy were also made in the more positive and enthusiastic responses to the broadcasting of this TV drama. Gay activist and then MP Franco Grillini (2006) noted how Il padre delle spose pointed to the close affiliations between Spain and Italy, thus suggesting how Italy should follow its country cousin's example along the path of social reforms, in particular with regard to the issue of gay marriage.

Zapatero's Spain seems to function here as a double signifier. It appears as the object of a 'desire for': a desire for reform, progress within a pan-European vision of liberal citizenship and civil rights. At the same time - particularly by means of the invocation of the 'deriva zapaterista' in more conservative commentaries - this desire appears to be 
repeatedly denied and understood as threatening for Italy. It is precisely the obsessive referencing of this threat which suggests, however, the power that this object of desire has gained in the Italian cultural imagery and the anxieties it creates about Italy's perception of its own liminal position in Europe.

\section{Puglia: a European region}

Italy's own regional differences complicate the production of a consistent Italian national identity but most importantly problematise ideas about the Europeanness of Italians. The long tradition of positioning North Italy as highly developed in its civic and economic habits and the regions of the south as socially and economically backward has enabled the Europeanness of southern Italy to be called into question; indeed, the differences between North and South have sometimes been understood in racialised terms (Gribaudi 1996; Schneider 1998). Whilst Il padre delle spose reproduces some of these associations by presenting a rural Apulian locale that is economically torpid and seemingly ill-prepared to deal with the modernising wind of Rosario's and Aurora's queer family, it also reveals a community increasingly willing to redefine its own moral, social and economic grounds. The setting of Il padre delle spose in Puglia is, in this sense, evocative of recent political and cultural transformations in southern Italy. Almost uncannily, in the last few years Puglia has followed a very similar trajectory to Spain. Once perceived to be a backward, conservative southern region, Puglia has dramatically rebranded itself as one of the most progressive and gay-friendly locales in Italy. Such rebranding has been partly a consequence of the surprising election of Nichi Vendola as the region's president and the policies and reforms that have been implemented by the Apulian government subsequently. An openly gay man and an ex-member of the Italian Communist Party, Vendola stormed to victory in the 2005 regional elections and was re-elected for a second mandate in 2010 after maintaining high levels of popular support. Vendola's rise has defied widely held assumptions about the South, where it was presumed that an openly gay man could never be elected to such a position (Fierro 2005). Only a few months into his first election, Vendola's government passed a law recognising the right of same-sex couples to receive welfare support. His government also launched one of the most radical programmes for green energy in Italy, setting more ambitious targets than the most environmentally friendly administrations of the regions of the north. Meanwhile Puglia has become also one of the most attractive cultural locales in Italy, as demonstrated by the Apulian government's strong support for numerous arts festivals and its drive to attract film production companies from all around Italy to the region. ${ }^{9}$ Il padre delle spose owes its very existence to funding provided by the Puglia regional government. ${ }^{10}$

The similarities between the recent developments in Puglia and Spain have not gone unnoticed in Italy. Centre-Right MPs Simona Licastro and Patrizia Paoletti Tangheroni condemned Vendola's reforms, especially those concerning same-sex couples, as 'un progetto pilota per portare in Italia il modello Zapatero' (gaynews.it 2006a). Conversely, Franco Grillini (2005) saluted the rise of an openly gay politician such as Vendola in Puglia as indicative of a more far-reaching realignment: 'Puglia, la vittoria più bella. L'Italia entra finalmente in Europa'. Grillini's words epitomise a familiar strategy in recent LGBT campaigns in Italy. In the last few years, the Italian LGBT movement has increasingly framed the struggle for its two main objects, a law recognising homophobic 
hate crime and one giving legal status to civil partnerships, as a fight whose ultimate reward will be Italy's full entrance into the European family. Europe equates here only with the Western and Northern European countries, the vast majority of which have such laws. According to its Italian organisers, the decision to hold the 2011 Europride in Rome stemmed precisely from their desire to stress Italy's shameful status in Europe with regard to the question of LGBT rights. This status was reinforced also by the interventions of several MEPs from countries such as Denmark, Germany and France at a conference organised by Italian MP Paola Concia where Italy's track record for LGBT rights was heavily criticised (Pasqua 2011, 7). For Andrea Maccarrone, spokesman for the European Pride Organiser Association, 'a differenza di tutti i fondatori dell'Unione Europea, [l'Italia] non riconosce alcun diritto agli omosessuali, mostrandosi invece più in linea con i paesi dell'est europeo, come la Polonia, ostacolati da una forte influenza religiosa' (Sinia 2011).

Once again, these comments about Puglia and Italy share a tendency to invoke an external entity (Spain, Europe, those that lie at the margins of Europe such as Poland) in order to read Italy's own image as either a backward or a progressive country. For the most progressive commentators such as Grillini and Maccarrone, this externality may either be attractive (i.e. liberal Western Europe) or threatening (i.e. Eastern Europe). Puglia is in itself an interesting example of this liminality within the national borders: it is a space that is seen at once as conservative and progressive, stuck with its traditions and its largely rural economy, yet moving forward with progressive social reforms and cuttingedge cultural and environmental programmes. Puglia's ambivalence also has to do with its own position as one of Italy's gateways to the east and the south. Under these terms Puglia constitutes both the embodied site of a 'threat' for Italy's much treasured national and European borders (as made evident by the mass arrival of Albanian migrants in the mid-1990s) as well as a multicultural space of integration and solidarity between migrant communities and indigenous ones (as suggested by Il padre delle spose through the welcoming in the community not only of the Spaniard Rosario but also of a minor character, a young Eastern European woman).

\section{Provincial life and the economically productive queer subject}

Il padre delle spose focuses on the possibilities and problematics of queer life in the provinces. The drama noticeably differs from the likes of Manuale d'amore 2 which abandon the restrictive Italian province for the hospitable European metropolis; whilst initially reiterating this trajectory in its move to Barcelona, Il padre delle spose reverses it with its subsequent return to rural Puglia. In doing so it shares with a handful of other recent Italian screen dramas an interest in queer provincial existence and even a preference for it over metropolitan life. ${ }^{11}$ What is especially interesting about Il padre delle spose is its working with locally situated traditions to envisage the creation of a more tolerant and dynamic community and the place that the lesbian protagonists have within this project. At the drama's opening, Aurora's home village of San Damiano is cast as a place of patriarchal restriction that stymies culture. The first sequence depicts her father expressing his determination that she will never study photography whilst living under his roof; presumably because they promise her economic independence, he equates her career ambitions with prostitution. Thus when Aurora and Rosario arrive in Puglia, their 
discovery that the local womenfolk are in a moribund state is hardly surprising. For instance, the women have given up the pizzica, the local traditional dance, because they are too encumbered with familial responsibilities to engage in any kind of female socialising. Rosario and Aurora set up a dance group for the women of the village which enables them to form a network of female solidarity and so escape their domestic seclusion. This creation of an autonomous female space is given architectural shape by the lesbian couple's renovation of a traditional trullo. After being thrown out of her family home by her father, Aurora, along with Rosario and her daughter, is given the use of a derelict trullo by her aunt Lucia who seeks to challenge her brother's patriarchal authority. The women occupy what is little more than a shell and transform it into a wholly feminine retreat. Aurora and Rosario are also the two main instigators of the creation of a small olive oil-producing co-operative, established to defend the local olive groves from corporate rapacity. A businessman's plan to buy up the groves in order to produce inferior quality oil on an industrial scale are thwarted by Aurora, who brings the wavering smallholders back onside after discovering that the EU offers funding for all-female business start-ups.

Aurora and Rosario's endeavours, optimistically perhaps, are shown to be culturally regenerative. But there is also clearly an economic dimension to their actions. The lesbian couple are shown to be entrepreneurial and ambitious. Their talents and initiative are repeatedly stressed against the lethargy of the local rural community. One can find here echoes of the argument, popularised by American academic Richard Florida (2002) and, from an Italian perspective, by Irene Tinagli in Talento da svendere (2008), that a society which is tolerant of diversity, and in which talent and technology are encouraged and valued, is more likely to be a prosperous one. In Italy such arguments have been employed in order to validate the contribution of queer talents to this prosperity in those contexts in which their presence is most tolerated and accepted. Indeed, in an open letter to L'Unità, spokespersons for the gay wing of the Democratic Party Paola Concia and Andrea Benedino invoke both Il padre delle spose and Florida's arguments:

Tante e tanti sono infatti le ragazze e i ragazzi italiani omosessuali che negli ultimi anni, come il personaggio di Aurora del film, stanno scegliendo di trasferirsi all'estero per vivere la propria vita più serenamente, sotto la tutela di legislazioni più avanzate e moderne, in un clima sociale più aperto alla creatività, all'innovazione e alla coesistenza di culture e vissuti diversi.... È un pezzo di classe creativa che se ne va, come direbbe Richard Florida, verso territori che sanno essere più attrattivi. $(2006,29)$

Concia and Benedino warn of the potential loss of queer talents to more tolerant locales, and they stress LGBT people's essential contribution to Italian prosperity. When used to legitimise claims for more rights for LGBT people, however, arguments such as Concia and Benedino's are problematic. At their heart is a strategy that subordinates the objective of creating a more inclusive society to that of prosperity, whereby the former becomes simply the condition for the latter. The kind of queer subject that is validated (and implicitly tolerated) is conceived within a market ideology that excludes all subjects other than the rational, wage-earning, wealth-maximising individual. Such assumptions may indicate the formation of what Lisa Duggan (2003) has named a new 'homonormativity', a neoliberal sexual politics predicated on a privatised, depoliticised gay culture anchored in domesticity and consumption.

Florida does not suggest that lesbians and gay men themselves cause economic growth as a consequence of their own spending power. Rather, places which are open and tolerant 
have an edge in attracting the 'creative class', a new grouping which includes scientists, engineers, university professors, artists, entertainers, designers, and architects. This class, Florida argues, plays a crucial role in the generation of new ideas which in turn open up economic opportunities. Very likely, the attractiveness of Florida's argument to LGBT commentators stems from his employment of the 'Gay Index', which measures the extent to which a region's population is made up of gay and lesbian people. For Florida this index is the prime reflector of the tolerance of a region, of its cultural vibrancy and therefore of its attractiveness to the creative class. An appealing aspect of Florida's account is the manner in which diversity is specifically valued; in fact, its value becomes precisely measurable. Yet, clearly, not all forms of diversity are appreciated. Whilst Florida's belief that 'a place that welcomes the gay community welcomes all kinds of people' $(2002,256)$ is certainly questionable, it is not difficult to identify which subjects might be excluded from this diverse society. Florida, for instance, admits that 'places that are open to immigrants do not necessarily number among the leading creative class centres' (ibid., 254-55). In Florida's account, certain kinds of diversity are privileged: principally, those that are comprised of, or are likely to attract, individuals who add economic value through their work.

With its happy, desexualised but economically productive lesbian family, Il padre delle spose arguably makes its demands for equality wholly within not only the exclusive norms of heterosexual coupling and intimacy, but also through a neoliberal outlook. Except for a brief kiss between Aurora and Rosario, the drama avoids any overt manifestations of lesbian desire, preferring instead to indulge in a family-friendly portrayal of domestic harmony. Il padre delle spose privileges a glossy, femme-centric aesthetic, which hardly upsets the dominant hetero-visual model for representing women. The drama undoubtedly contributes to asserting a sunny, optimistic vision for the future of LGBT people in Italy. Consistent with the need of mainstream TV for happy endings, Il padre delle spose relies on a neoliberal macro-narrative of individual self-assertion, prosperity and success. It is a macro-narrative which - especially when applied to LGBT people - tends to concentrate on stories of aspiring, middle-class individuals, privileged by social and economic mobility, whilst conveniently neglecting stories of queer failure (Halberstam 2011) and denied opportunities. And yet, Il padre delle spose does offer a critique of the perverse idea of freedom sometimes promulgated by neoliberalism - namely 'the freedom to exploit one's fellows, or the freedom to make inordinate gains without commensurable service to the community' (Harvey 2005, 36) - through the portrayal of the businessman who aspires to rob the community of its resources (the olive groves) for his personal gain.

Further, it is not entirely the case that the drama subordinates the objective of tolerance to that of affluence: the most salient transformation effected by the lesbian couple does seem to be the regeneration of various local traditions and, particularly, very public forms of female solidarity, such as the women-only gatherings where they dance the pizzica. Moreover, the drama maintains that the importation of metropolitan models of sexuality into a non-metropolitan context does not simply improve that locality; more likely such an encounter will be mutually transformative, a point which is made clear by the ambivalent way in which the drama handles the question of gay visibility. The act of coming out, which organises so much gay and lesbian narrative (Sinfield 2000; Saxey 2008), is relegated in importance in Il padre delle spose. In Puglia, Aurora and Rosario, full of caution, are continually trying to pass. The only 'classical' coming-out scene occurs when Rosario confirms her lesbianism to Lucia. Lucia's response is ambivalent. 
She declares she will love Aurora and Rosario because they are good people; in other words, she will ignore their homosexuality, which in any case, she declares, she could never consider the same as the love she has for her man. One may be initially disappointed with this denouement, which seems to show the limits of a mainstream TV drama and its unrepentant heterosexism. Yet, Lucia's minimal acknowledgement suggests that disclosure of sexual identity in this local situation may be simply ineffectual, if not redundant. A more felicitous way of living as queers in this locale, the drama suggests, is to identify struggles in common and, once again, to engage in local forms of association. This is precisely what Rosario seems to learn from her time in Puglia - after having suggested, in the Barcelona section, that she could not possibly understand Aurora's unwillingness to come out to her father. The drama does not, though, conclude with the lesbian protagonists' wholesale assimilation; their integration also enacts change in the workings of the community. For instance, Riccardo has to reconsider his ideas about what makes an honest and righteous man after struggling to reconcile his role as his community's moral standard-bearer with having a lesbian daughter. The climactic scene in which he walks across the town square proudly holding his daughter's and her wife's arms in the face of the homophobic bullying of the businessman is arguably the most striking testament to the drama's willingness to question established moral norms and ideas of community, individual freedom and respect for others.

In conclusion, the popular but controversial television drama Il padre delle spose provides a useful case study with which to evaluate the relationships between place, nation and LGBT politics in Italy today - a set of relationships that are in considerable flux. It articulates widely held anxieties over the country's place and direction within contemporary Europe, as the continent and even the constituent parts of Italy are undergoing dramatic realignment. With the contrasts it draws between metropolitan, tolerant Spain and provincial, restrictive Italy, Il padre delle spose seems to parallel the principal discursive strategy employed by Italian LGBT activists, who argue Italy must reform itself in order that the country properly 'belong' to Europe once more. Yet ultimately the drama pulls back from this kind of analysis; such vociferous discourse on Italy's place in a cosmopolitan, metropolitan Europe seems to distract attention from other pressing matters, such as what it might mean for LGBT people to live in non-metropolitan locations. At a moment when ideas about sexuality are still dominated by Anglo-American models and notions of Europeanness are regularly deployed to instruct people on how to organise their sexuality, Il padre delle spose helpfully points towards local solutions that are not wholly based on individualism or economic productivity yet which make clear some of the complications relating to LGBT life in such places.

\section{Notes}

1. For other responses, see for example: Volpe (2006); Patruno (2006); Costanzo (2006); Carugati (2006).

2. The debate escalated between 2006 and 2008 as the Prodi government struggled and ultimately failed to pass any kind of legislation on same-sex partnerships due to internal divisions within its centre-left majority and in the face of outright hostility from the centre-right opposition parties. For a detailed account of this debate, and of the heated responses that the topic of same-sex unions ignited during this period, see the documentary Improvvisamente l'inverno scorso (dir. Ragazzi and Hofer 2008). 
3. Un difetto di famiglia and Mio figlio, both focusing on gay male characters, had been previously broadcast by RAI in 2002 and 2005 respectively. Luca Malici (2011) asserts that, in the 1990s, the representation of LGBT people - actually mainly gay men - on Italian television was largely limited to films and shows imported from the US, though these were often subject to censorship. Since the mid 2000s, imported shows such as The L-word $(\mathrm{La} 7,2005)$ and Queer eye for the straight guy (I fantastici 5, La7, 2004) have been broadcast uncut, though not without attracting criticism from conservative quarters. We would contend that numerous other television texts from earlier periods have provided Italian LGBT people with useful resources. More attention might be paid, for instance, to the strikingly queer content of imported animated series such as Lady Oscar (Italia 1, 1982) and C'era una volta ... Pollon (Italia 1, 1984).

4. Other reforms include legislation passed in 2004 to speed up divorce proceedings, the Gender Equality Act of 2006, and the ending of compulsory teaching of Catholicism in public schools in 2007.

5. A similar point is also made by Claudia Cucchiarato: 'Spagna e Italia, è risaputo, sono paesi simili. Con i "cugini" spagnoli abbiamo molte cose in comune.... Gli spagnoli, tuttavia, sono sempre stati guardati dagli italici come un popolo tutto sommato inferiore' $(2010,26)$.

6. According to The global gender gap report 2010, Spain has been competing since 2006 with Scandinavian countries for the top rankings and currently scores 11 th in the world, whilst Italy's position, in the same period, has fluctuated between 67 th and the 84th (Hausman, Tyson, and Zahidi 2010, 8). Celia Valiente (2008) offers a more measured assessment of gender equality in Spain since the Zapatero reforms. For instance, the Spanish state has failed to properly implement the Gender Violence Act of 2004, and there has been opposition to the Gender Equality Act of 2006 from employers' organisations.

7. A significant number of articles on Zapatero and his progressive reforms have appeared in Italian magazines and newspapers asking what these social reforms mean for Italy. See for example: Vignolo (2004); Oppes (2004); Merlo (2005).

8. According to the Dizionario Treccani dei neologismi, the first recorded uses of these terms occurred in 2004.

9. Notably, in response to the lack of financial support from the newly elected regional government of Piedmont (led by Lega Nord), the director of the 2010 Turin gay and lesbian film festival Giovanni Minerba threatened to move this prestigious event to Puglia (Caroli 2010, 1).

10. Another key supporter of the drama was the Apulian actor and national television star Lino Banfi, who plays Riccardo, and who is father to the actress playing Aurora, Rosanna Banfi. Lino Banfi's involvement parallels Puglia's recent transformations. A rather conservative public figure, Banfi vigorously defended this project against its critics. The involvement of Banfi was surprising especially for those who were critical of RAI's decision to broadcast the drama. Luca Borgomeo, president of the Association of Catholic TV viewers (AIART), declared: 'davvero strano che il ruolo del padre sia stato affidato a Lino Banfi, che finora ha vestito i panni dell'amorevole e rassicurante nonno, quasi un garante della famiglia italiana' (aiart.org).

11. In the film Mater natura (dir. Andrei, 2005), for example, a group of transsexuals and femminielli, disappointed with life in the city, leave Naples and set up a queer rural community on Mount Vesuvius. In a similar vein, Ferzan Ozpetek's most recent film, Le mine vaganti (2010), which is entirely set in the small provincial town of Lecce, shows two gay brothers establishing affective relationships and envisaging the possibility of living as queers away from the metropolis.

\section{Notes on contributors}

Martin Dines is Senior Lecturer in English Literature at Kingston University, London. He is the author of Gay Suburban Narratives in American and British Culture: Homecoming Queens (Basingstoke: Palgrave, 2010) and is a member of the Leverhulme Trust funded Cultures of the Suburbs International Research Network.

Sergio Rigoletto is a Teaching Fellow in Italian Studies at the University of Reading. He is the author of Masculinity and Italian Cinema: Sexual Politics, Social Conflict and Male Crisis in the 
1970s (forthcoming with Edinburgh University Press) and co-editor, with Louis Bayman, of Popular Italian Cinema (forthcoming with Palgrave).

\section{References}

Cucchiarato, C. 2010. Vivo altrove. Milan: Bruno Mondadori.

Downing, L. and R. Gillet, eds. 2011. Queer in Europe: Contemporary case studies. Farnham: Ashgate.

Duggan, L. 2003. The twilight of equality? Neoliberalism, cultural politics, and the attack on democracy. Boston: Beacon Press.

Duncan, D. 2006. Reading and writing Italian homosexuality: A case of possible difference. Aldershot: Ashgate.

Florida, R. 2002. The rise of the creative class. New York: Basic Books.

Gribaudi, G. 1996. Images of the South. In Italian cultural studies: An introduction, eds. D. Forgacs and R. Lumley, 72-87. Oxford: Oxford University Press.

Halberstam, J. 2011. The queer art of failure. Durham, NC: Duke University Press.

Harvey, D. 2005. A brief history of neoliberalism. Oxford: Oxford University Press.

Hausman, R., L.D. Tyson and S. Zahidi. 2010. The global gender gap report 2010. Geneva: World Economic Forum.

Malagreca, M. 2007. Queer Italy: Contexts, antecedents and representation. New York: Peter Lang.

Malici, L. 2011. Queer in Italy: Italian televisibility and the 'queerable' audience. In Queer in Europe: Contemporary case studies, eds. L. Downing and R. Gillett, 113-28. Farnham: Ashgate.

Mizielinska, J. 2006. Queering Moominland: The problems of translating queer theory into a non-American context. SQS: Journal of queer studies in Finland 1: 87-104.

Pustianaz, M. 2010. Qualche domanda (sui) queer in Italia. Italian Studies 65, no. 2: 263-77.

Saxey, E. 2008. Homoplot: The coming-out story and gay, lesbian and bisexual identity. New York: Peter Lang.

Schneider, J. 1998. Italy's 'southern question': Orientalism in one country. Oxford: Berg.

Sinfield, A. 2000. The production of gay and the return of power. In De-centering sexualities: Politics and representations beyond the metropolis, eds. R. Phillips, D. Shuttleton and D. Watt, 21-36. London: Routledge.

Spurlin, W.J. 2000. Remapping same-sex desire: Queer writing and culture in the American heartland. In De-centering sexualities: Politics and representations in the metropolis, eds. R. Phillips, D. Shuttleton and D. Watt, 182-98. London: Routledge.

Tinagli, I. 2008. Talento da svendere. Turin: Einaudi.

Valiente, C. 2008. Spain at the vanguard in European gender equality policies. In Gender politics in the expanding European Union: Mobilization, inclusion, exclusion, ed. S. Roth, 101-19. New York: Berghahn.

\section{Articles in newspapers and websites}

aiart.org. Il padre delle spose: dibattito nella rubrica Omnibus su la7. http://www.aiart.org/ita/web/ item.asp?nav $=963$ (accessed 23 May 2007).

Caroli, C. 2010. Tagliano i fondi al cinema gay? E noi chiediamo asilo a Vendola. La Repubblica, 3 April, Turin supplement.

Carugati, A. 2006. Lo strano caso della senatrice Binetti. L'Unità, 23 November.

Casadio, G. 2005. Il sì di Fini spacca il governo. La Repubblica, 11 May.

Cazzullo, A. 2008. Spagna bestia nera ma l'Italia sportiva sogna la rivincita. Il Corriere della Sera, 10 August.

Concia, P. and A. Benedino. 2006. Lesbo-fiction: l'Italia che va avanti. L'Unità, 23 November. 
Il Corriere della Sera. 2008. Berlusconi? Gli pago io uno psichiatra. 18 May.

Costanzo, M. 2006. L'inaccettabile normalità della diversità. Il Riformista, 28 November.

Dizionario Treccani dei neologismi. http://www.treccani.it/magazine/lingua_italiana/neologismi/ searchNeologismi.jsp?lettera $=$ Z\&pathFile $=/$ sites $/$ default $/$ BancaDati $/$ Osservatorio_della Lingua_Italiana/OSSERVATORIO_DELLA_LINGUA_ITALIANA_ND_018042.xml $\bar{\varepsilon}$ lettera $=\mathrm{Z}$ (accessed 23 June 2011).

Fierro, E. 2005. Puglia, la scommessa Vendola. L'Unità, 20 March.

Franco, R. 2006. La fiction con Banfi sulle nozze lesbiche divide anche l'Unione. Il Corriere della Sera, 21 November.

gaynews.it. 2006a. Forza Italia. Le donne. No in Puglia al modello Vendola-Zapatero, January 21. http://www.gaynews.it/view.php?ID = 35848 (accessed 23 June 2011).

gaynews.it. 2006b. Landolfi: Fiction lesbiche? Sbagliato la tesi zapaterista, 21 November. http:// gaynews.it/view.php?ID = 71167 (accessed December 11, 2009).

Grillini, F. 2005. Regionali. Puglia, la vittoria più bella. L'Italia entra finalmente in Europa, 4 April. http://www.gaynews.it/view.php?ID = 31633 (accessed December 30, 2010).

Grillini, F. 2006. Rai. Grillini: fiction con lesbiche? Giovanardi dice sciocchezze. 21 November. http://www.arcigaymilano.org/stampa/dosart.asp?ID = 27691 (accessed 7 March 2010).

Hooper, J. 2008. Trading places. Guardian, 5 March.

Merlo, F. 2005. Chi agita il fantasma di Zapatero. La Repubblica, 4 July.

Oppes, A. 2004. Zapatero, rivoluzione in 100 giorni. La Repubblica, 26 July.

Pasqua, M. 2011. Diritti GLBT, Italia è un paese di serie C. Il giudizio dei parlamentari europei. La Repubblica, 10 June.

Patruno, F. 2006. Film Banfi, polpetta di terzo livello. L'Osservatorio Romano, 21 November.

La Repubblica. 2006. Il ministro: "Leggi sulle unioni di fatto" Ma Prodi frena, 16 June.

Sinia, Y. 2011. L'unione Europride. Il manifesto, 9 June.

Volpe, M. 2006. Fiction sulle nozze lesbo, elogi da sinistra. L'affondo del polo: è una Rai zapaterista. Il Corriere della Sera, 22 November.

Vignolo, M. 2004. Divorzi facili e nozze gay: la rivoluzione di Zapatero. Il Corriere della Sera, 17 September.

\section{Filmography}

Caterina e le sue figlie 2. TV series. Canale 5, 2007.

Caterina e le sue figlie 3. TV series. Canale 5, 2010.

C'era una volta... Pollon. TV Series. Fuji Television, 1982-83 (Italia 1, 1984).

Un difetto di famiglia. Directed by Alberto Simone. Rai fiction, Italian International Film \& Towers of London productions, RAI2, 2002.

Improvvisamente, l'inverno scorso. Directed by Gustav Hofer \& Luca Ragazzi, HIQ Productions, 2008.

Italo-spagnolo. TV series. MTV Italy, 2006.

Lady Oscar. TV Series. Tokyo Movie Shinsha, NTV, 1979 (Italia 1, 1982).

The L-Word. TV Series. Showtime, 2004 (La7, 2005).

Ma la Spagna non era cattolica?. Directed by Peter Marcias. Ultima Onda, 2007.

Manuale d'amore 2. Directed by Giovanni Veronesi. Filmauro, 2007.

Mio Figlio. Directed by Luciano Odorisio. Rai fiction \& Sacha film, RAI1, 2005.

Il padre delle spose. Directed by Lodovico Gasparini. Publispei, Rai fiction \& Zeta Produzioni, RAI1, 2006.

Queer eye for the straight guy. TV Series. Bravo, 2003 (I fantastici 5, La7, 2004).

Viva Zapatero!. Directed by Sabina Guzzanti. Lucky Red, Sciocco Produzione, Secol Superbo \& Studio Uno, 2005. 